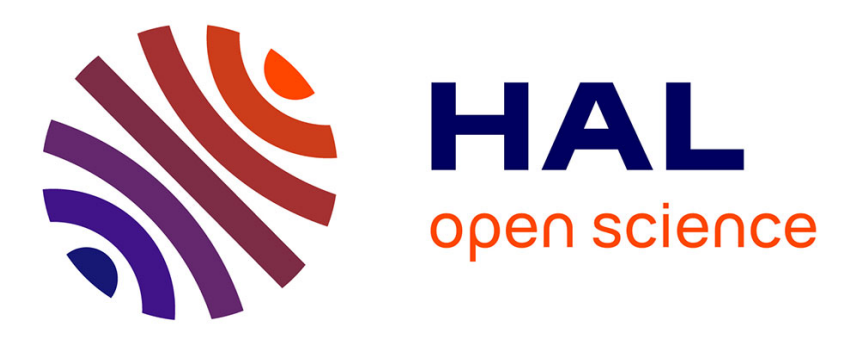

\title{
The Redox Chemistry of Mono- and Bis(acyl)phosphane Oxides
}

\author{
Michal Zalibera, Pierre-Nicolas Stebe, Kurt Dietliker, Hansjorg Grützmacher, \\ Martin Spichty, Georg Gescheidt
}

\section{> To cite this version:}

Michal Zalibera, Pierre-Nicolas Stebe, Kurt Dietliker, Hansjorg Grützmacher, Martin Spichty, et al.. The Redox Chemistry of Mono- and Bis(acyl)phosphane Oxides. European Journal of Organic Chemistry, 2014, 2014 (2), pp.331-337. 10.1002/ejoc.201301214 . hal-02929367

\section{HAL Id: hal-02929367 https://hal.science/hal-02929367}

Submitted on 26 Nov 2020

HAL is a multi-disciplinary open access archive for the deposit and dissemination of scientific research documents, whether they are published or not. The documents may come from teaching and research institutions in France or abroad, or from public or private research centers.
L'archive ouverte pluridisciplinaire HAL, est destinée au dépôt et à la diffusion de documents scientifiques de niveau recherche, publiés ou non, émanant des établissements d'enseignement et de recherche français ou étrangers, des laboratoires publics ou privés. 


\title{
The Redox Chemistry of (Bis)Acylphosphaneoxides
}

\author{
Michal Zalibera, ${ }^{[a]}$ Pierre-Nicolas Stébé, ${ }^{[b]}$ Kurt Dietliker, ${ }^{[c]}$ Hansjörg Grützmacher, ${ }^{[c]}$ Martin \\ Spichty, ${ }^{[b]}$ and Georg Gescheidt ${ }^{*[a]}$
}

Dedicated to ... on the occasion of ... ((optional))

Keywords: Photoinitiator / Radical anion / Cyclovoltammetry / EPR

Mono- and bisacylphosphaneoxides are usually utilized as photoinitiators for radical polymerizations. This manuscript reveals the electrochemically reversible reductions of these molecules, leading to the corresponding radical anions.
The radical anions are characterized by EPR and ENDOR spectroscopies. They display remarkable delocalization and ionpairing phenomena, which can be rationalized by theoretical calculations. [a] Dr. Michal Zalibera, Prof. Dr. G. Gescheidt Institute of Physical and Theoretical Chemistry Graz University of Technology

— Stremayrgasse 9, A-8010 Graz (Austria) Fax: (+43 316873 32202)

E-mail: g.gescheidt-demner@tugraz.at

Homepage: URL of homepage

[b] P.-N. Stébé, Dr. M. Spichty

Laboratory of Molecular and Cellular Biology, Differentiation and the Cell Cycle

Ecole Normale Supérieure de Lyon

46, allée d'Italie, 69364 Lyon, cedex 07, (France)

[c] Dr. K. Dietliker, Prof. Dr. H. Grützmacher

Laboratory of Inorganic Chemistry

ETH Zürich

Supporting information for this article is available on the WWW under http://dx.doi.org/10.1002/ejoc.xxxxxxxxx.

\section{Introduction}

Mono(acyl) and bis(acyl)phosphaneoxides, MAPOs and BAPOs, are among the most successful photoinitiators utilized to start radical polymerization reactions with a very high efficiency ${ }^{[1]}$. They are widely used for a variety of coatings processes and are especially useful for the curing of thick layers and highly pigmented formulations. The unique bleaching of the longwavelengths absorption makes them especially suitable for use in white coatings. ${ }^{[2]}$ Apart from their industrial relevance, the parent molecules and their follow-up products have prominent optical absorption bands ${ }^{[1 b, 1 c]}$ and are well suited for spectroscopic investigations $\left.{ }^{[1 \mathrm{f},} 3\right]$ providing detailed understanding of the elemental chemical steps involved in these applications.

Despite their widespread use, the fundamental chemistry of MAPOs and BAPOs is little explored. A yet underestimated property of phosphaneoxides is their ability to accept electrons. It was shown that a variety of phosphaneoxides can be reduced by chemical and electrolytic reduction, yielding EPR spectra. ${ }^{[4]} \mathrm{We}$ have performed cyclovoltammetric measurements and recorded
EPR/ENDOR spectra of one-electron reduced photoinitiators MAPOs and BAPOs 1-4. Their electronic properties have been investigated with density functional theory (DFT) calculations.

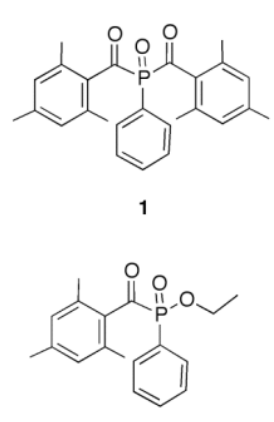

3
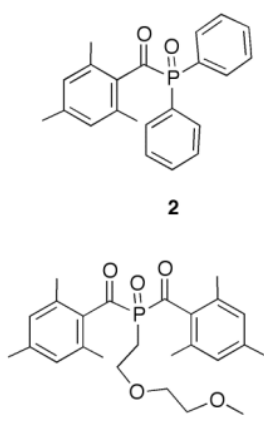

Scheme 1. Bis- and Mono-Acylphosphaneoxides 1-4

\section{Results and Discussion}

Cyclic voltammograms (CV) of 1-4 (Figure 1) reveal quasireversible reduction peaks with $E_{1 / 2}$ between -1.8 and $-2.04 \mathrm{~V}$ vs. $\mathrm{Fc}^{+} / \mathrm{Fc}$ (Table 1). The reduction potentials of bisacylphosphaneoxides $\mathbf{1}$ and $\mathbf{4}$ are approximately $200 \mathrm{mV}$ less negative than those of monoacyl compounds $\mathbf{2}$ and $\mathbf{3}$. Notably, the reduction potentials of 1-4 are markedly less negative than those of acetophenone (AC) and benzophenone (BP) ${ }^{[5]}$, indicating that the $\mathrm{R}_{3} \mathrm{P}=\mathrm{O}$ moiety contributes to the electron-accepting ability in $\mathbf{1 - 4}$ and allows electron delocalization in spite of its pyramidal geometry. ${ }^{[6]}$ 

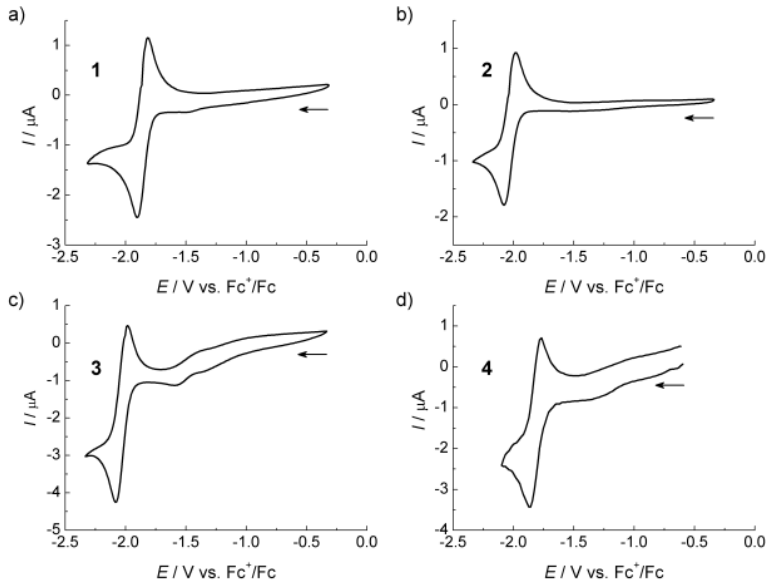

Figure 1. Cyclic voltammograms of 1-4 $\left(0.5 \mathrm{mM}\right.$, solvent, $\mathrm{CH}_{3} \mathrm{CN}$; supporting electrolyte, $0.1 \mathrm{M}$ tetrabutylammonium perchlorate) using a $\mathrm{Pt}$ working electrode, Pt counter electrode and $\mathrm{Ag}$ pseudo-reference electrode (potentials are given vs. $\mathrm{Fc}^{+} / \mathrm{Fc}$ ) and $100 \mathrm{mVs}^{-1}$ scan rate. The direction of the potential sweep is indicated by the arrow.

Table 1. Reduction potentials and CV peak separations for 1-4 (all values vs. $\left.\mathrm{Fc}^{+} / \mathrm{Fc}\right)$

\begin{tabular}{lllllll}
\hline & $\mathbf{1}$ & $\mathbf{2}$ & $\mathbf{3}$ & $\mathbf{4}$ & $\mathbf{B P}^{[\mathrm{c}]}$ & $\mathbf{A P}^{[\mathrm{c}]}$ \\
\hline$E_{1 / 2} / \mathrm{V}^{[\mathrm{a}]}$ & -1.86 & -2.03 & -2.04 & -1.81 & -2.23 & -2.60 \\
$\Delta E_{\mathrm{p}} / \mathrm{mV}^{[\mathrm{b}]}$ & 89 & 98 & 99 & 97 & - & - \\
\hline
\end{tabular}

[a] $E_{1 / 2}=\left(E_{\mathrm{pc}}+E_{\mathrm{pa}}\right) / 2, E_{\mathrm{pc}}, E_{\mathrm{pa}}$ are cathodic and anodic peak potentials, respectively [b] $\Delta E_{\mathrm{p}}=\left(E_{\mathrm{pa}}-E_{\mathrm{pc}}\right)[\mathrm{c}]$ Taken from $\operatorname{Ref}^{[5]}$ and recalculated to $\mathrm{Fc}^{+} / \mathrm{Fc}$ as the reference

The quasi-reversible character of the voltammetric peak indicates that radical anions of 1-4 should be rather persistent. Indeed electrochemical (Pt-mesh working electrode) and chemical (K metal in THF, DME, and DME/HMPA) reduction (Scheme 1) led to well-distinguishable EPR spectra, attributed to $\mathbf{1}^{-\mathbf{-}} \mathbf{4}^{\mathbf{*}}$. In chemically reduced samples, signal intensities remain constant at temperatures below $-40{ }^{\circ} \mathrm{C}$. Warming of the solutions to room temperature leads to a substantial decrease of the EPR signal, revealing the decomposition of radical anions into EPR silent products.

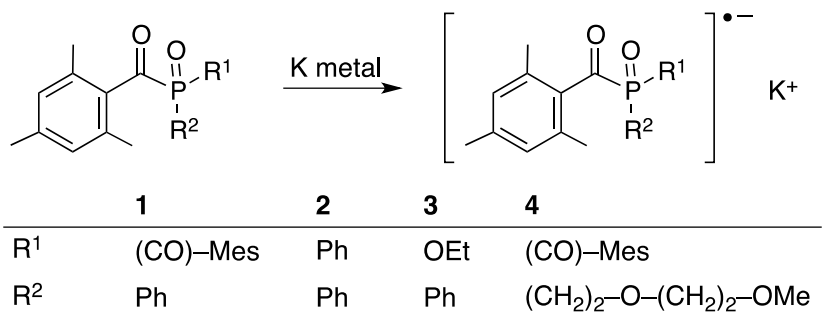

Scheme 2. Reduction of 1-4 leading to the corresponding persistent radical anions $\mathbf{1}^{0^{-}-\mathbf{4}^{\bullet}}$

The EPR spectra are only fairly resolved and dominated by ${ }^{31} \mathrm{P}$ isotropic hyperfine coupling constants (hfcs) of 2-2.5 $\mathrm{mT}$. Noteworthy, the EPR spectra are better resolved, when the radical anions are generated by electrolysis (Figure 2 and SI).
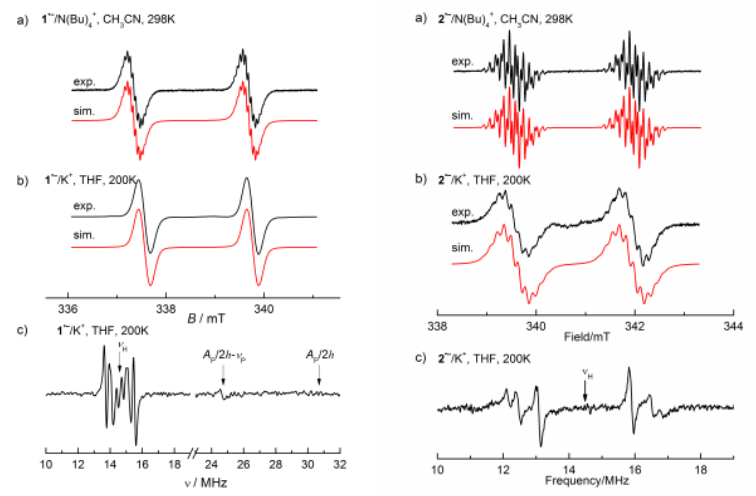

Figure 2. a) EPR spectra obtained by electrochemical reduction (Pt cathode, $\mathrm{g}=2.0042$ ) of $\mathbf{1}$ and $\mathbf{2}$ (solvent $\mathrm{CH}_{3} \mathrm{CN}$, supporting electrolyte, $\left.\mathrm{N}(\mathrm{Bu})_{4} \mathrm{ClO}_{4}\right)$, with the simulation, $\mathrm{T}=298 \mathrm{~K}$; b) EPR spectrum of $\mathbf{1}$ after chemical reduction with $\mathrm{K}$ in $\mathrm{THF}, \mathrm{T}=200 \mathrm{~K}$, with the simulation; c) corresponding ENDOR spectrum $(\mathrm{THF}, \mathrm{T}=200 \mathrm{~K})$.

We were able to obtain ENDOR spectra for all radical anions generated by the K-metal reduction. They provided, the absolute values of the ${ }^{1} \mathrm{H}$ hfcs, not discernible in the EPR spectra, as well as the ${ }^{31} \mathrm{P}$ hfcs. This does not only lead to a satisfying simulation of the EPR spectra, but also allows estimation of the amount of spin transferred into the aryl and alkyl substituents (Table 2).

As an example, Figure 2 shows the experimental EPR and ENDOR spectra of $\mathbf{1}^{-}$- together with the corresponding EPR simulations. The ${ }^{1} \mathrm{H}$ hfcs of $0.060 \mathrm{mT}(6 \mathrm{H}), 0.039 \mathrm{mT}(12 \mathrm{H})$, and $0.012 \mathrm{mT}(4 \mathrm{H})$ can be easily discerned in the ENDOR spectrum, whereas they are not resolved in the EPR signals. The EPR data of $\mathbf{1}^{-}-\mathbf{4}^{-}$are summarized in Table 2.

The ${ }^{1} \mathrm{H}$ hfcs multiplicities obtained for BAPO $1^{-}$indicate, that the spin and the charge are evenly distributed within the two mesityl substituents, whereas the P-phenyl group does not carry detectable spin. The two mesityl groups are not equivalent in BAPO 4*-, presumably due to the decrease of the overall symmetry by the 3,6-dioxoheptyl substituent at $\mathrm{P}(\mathrm{O})$. MAPO $\mathbf{2}^{\mathbf{*}^{-}}$reveals three ${ }^{1} \mathrm{H}$ hfcs of $0.142,0.165$, and $0.100 \mathrm{mT}$, due to 6,3 , and 2 protons, respectively, attributable to the ortho and para methyl groups and the two meta protons of the mesitoyl moiety. Analogous multiplicities hold for MAPO $3^{-}$. Accordingly, it can be deduced, that delocalization is exclusively confined to the electronwithdrawing substituents. The (not markedly) differing absolute values of the sets of hfcs indicate, that the alkyl and phenyl substituents produce electronic effects, however, without participating in electron delocalization.

The development of DFT calculations in recent years, has provided relatively accurate predictions of hfc values in organic radicals ${ }^{[7]}$. It is thus rather remarkable that for $\mathbf{1}^{-}-\mathbf{4}^{-}$the ${ }^{1} \mathrm{H}$ and ${ }^{31} \mathrm{P}$ hfcs calculated by DFT (Table 2) differ significantly from the experimental values. In addition to the basis sets given in Table 3, we tested for the most populated conformer of $\mathbf{1}^{-}$a large variety of different basis sets (including EPR-III, cc-pVTZ), their impact was marginal (data not shown). The calculation systematically overestimates the ${ }^{1} \mathrm{H}$ hfcs. This may be traced back to ion pairing, where ion pairs between the two (formally negative) oxygen atoms and the counterion could lead to conformations, which markedly alter the spin distribution and thereby change the hyperfine coupling in the mesitoyl substituent. Indeed, with ion-paired states included into the calculations, the agreement between experimental and calculated ${ }^{1} \mathrm{H}$ hfcs improves substantially. 
Table 2. ${ }^{31} \mathrm{P}$ and ${ }^{1} \mathrm{H}$ hfcs (/mT, values in parentheses indicate the number of equivalent nuclei) together with their calculated counterparts (UB3LYP $\left.[\mathrm{PCM}=\mathrm{THF}] / 6-311^{++} \mathrm{G}^{* *}\right)$ and $\mathrm{g}$ factors for $\mathbf{1}^{-}-\mathbf{4}^{-}\left(\mathrm{K}^{+} / \mathrm{THF}, \mathrm{T}=\right.$ $200 \mathrm{~K}$ ). Calculated hfcs $<0.03 \mathrm{mT}$ are not listed (see instead Table S2, Supporting Information).

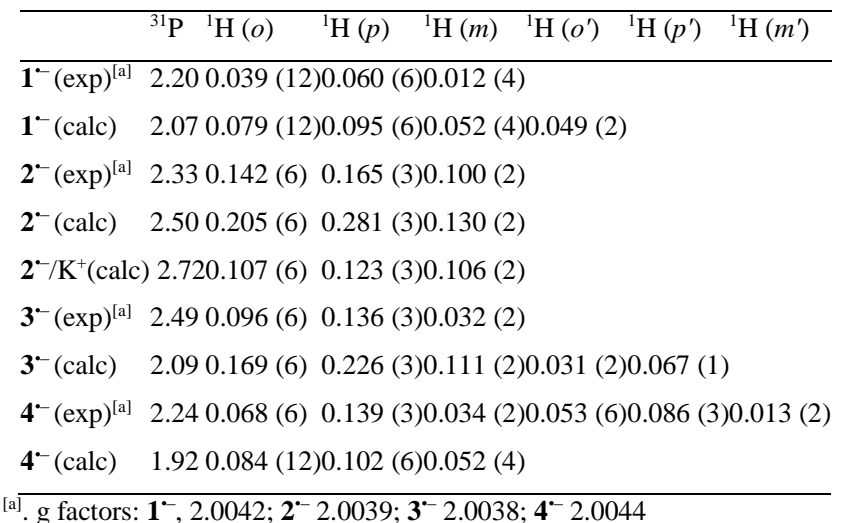

A more detailed insight into these ion-pairing phenomena, is presented with MAPO radical anion $\mathbf{2}^{-\boldsymbol{}}$ as a paradigm. The results are summarized in Table 3. Changes of the basis set have some influence on the ${ }^{31} \mathrm{P}$ hfc, while the ${ }^{1} \mathrm{H}$ hfcs hardly alter. However, introduction of either $\mathrm{K}^{+}$or $\mathrm{Et}_{4} \mathrm{~N}^{+}$, as the counterion, leads to a marked change in the ${ }^{1} \mathrm{H}$ hfcs. The hfcs for the six equivalent methyl protons in the ortho position and the three para (methyl) protons are almost halved in the presence of $\mathrm{K}^{+}$, and the effect is well distinguishable but less pronounced for $\mathrm{Et}_{4} \mathrm{~N}^{+}$. Clearly, this is not a consequence of the use of different basis-sets, but a result of the specific interactions between the radical anion and its environment. The ion pairing leads also to a shift in the population of conformational states. In the absence of the counterion, there exists only a single conformational minimum for $\mathbf{2 a}^{\mathbf{}}$ with the two oxygen bonds in trans configuration (Figure 3 ). In the presence of $\mathrm{K}^{+} / \mathrm{Et}_{4} \mathrm{~N}^{+}$additional conformers can be identified. The conformational equilibrium shifts from trans to cis upon ion pairing The cis conformer $\mathbf{2} \mathbf{b}^{-}$has significantly lower ${ }^{1} \mathrm{H}$ hfcs than the trans conformers $\mathbf{2 a}$ ' or $\mathbf{2 a}$ "'.
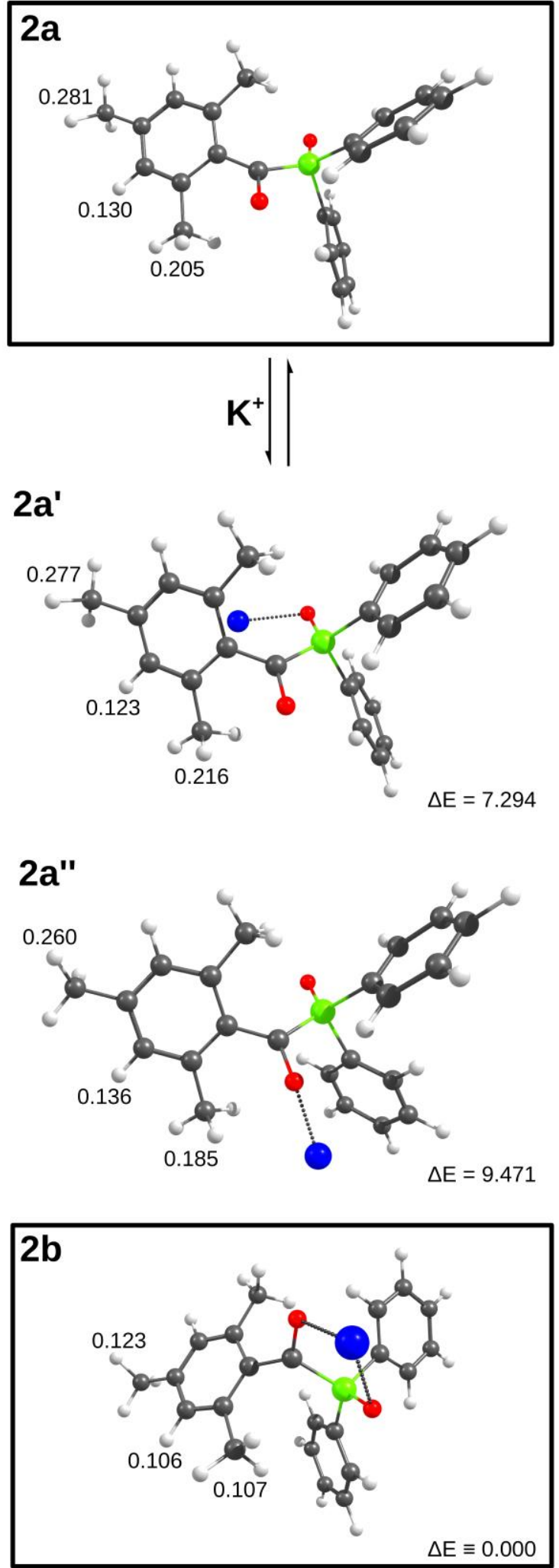

Figure 3. The calculated conformers of $\mathbf{2}^{-}$.in the absence (top) and presence (bottom) of the counterion $\mathrm{K}^{+}$. Dominant conformers are indicated by a frame. The ${ }^{1} \mathrm{H}$ hfcs of the mesitoyl ring are shown (in $\mathrm{mT}$ ) as well as the relative energy (UB3LYP $[\mathrm{PCM}=\mathrm{THF}] / 6-311^{++} \mathrm{G}^{* *}$, in $\mathrm{kcal} / \mathrm{mol}$ ) for the ion pairs.

For the ${ }^{31} \mathrm{P}$ hfcs of $\mathbf{1}^{--} \mathbf{4}^{--}$the deviation between calculation and experiment seems to be less systematic than for the ${ }^{1} \mathrm{H}$ hfcs. 
The calculation of the ${ }^{31} \mathrm{P}$ hfcs is extremely sensitive to the geometry of these radical anions. For example, a rotation of the mesitoyl ring between two rotamers of $3^{-}$can alter the ${ }^{31} \mathrm{P}$ hfc by $0.6 \mathrm{mT}$ (see also Figue S3). A more accurate calculation of the ${ }^{31} \mathrm{P}$ hfc for MAPO and BAPO radical anions may therefore require an approach that integrates accurate calculation of conformer populations (conformational free energies) and explicit treatment of solvent and counterion effects.

Table 3. ${ }^{31} \mathrm{P}$ and ${ }^{1} \mathrm{H}$ hfcs (/mT) for $\mathbf{2}^{-}$with different basis sets, solvent models, and counterions. The hfcs of the phenyl substituents are not listed since they are substantially smaller than those of the mesitoyl substituent. The complete data are presented in the Supporting Information Table S2).

\begin{tabular}{|c|c|c|c|c|}
\hline & \multirow[t]{3}{*}{${ }^{31} \mathrm{P}$} & \multicolumn{2}{|c|}{${ }^{1} \mathrm{H}$ - mesitoyl } & \multirow{3}{*}{$\begin{array}{l}p-\mathrm{Me} \\
3 \mathrm{H}\end{array}$} \\
\hline & & $o-\mathrm{Me}$ & $m$ & \\
\hline & & $6 \mathrm{H}$ & $2 \mathrm{H}$ & \\
\hline $6-31+\mathrm{G}^{*}$ & -2.029 & 0.209 & 0.131 & 0.282 \\
\hline $6-311++\mathrm{G}^{* *} / 6-31+\mathrm{G}^{*}$ & -2.395 & 0.200 & 0.121 & 0.275 \\
\hline $6-311++\mathrm{G}^{* *} / 6-31+\mathrm{G}^{*}$ & -2.502 & 0.205 & 0.130 & 0.281 \\
\hline \multicolumn{5}{|l|}{$[\mathrm{PCM}=\mathrm{THF}]$} \\
\hline \multicolumn{5}{|l|}{ with counterion $\mathrm{K}^{+}$} \\
\hline $6-31+\mathrm{G}^{*}$ & -2.385 & 0.108 & 0.112 & 0.119 \\
\hline $6-311++\mathrm{G}^{* *} / 6-31+\mathrm{G}^{*}$ & -2.773 & 0.104 & 0.106 & 0.117 \\
\hline $6-311++\mathrm{G}^{* *} / 6-31+\mathrm{G}^{*}$ & -2.724 & 0.107 & 0.106 & 0.123 \\
\hline \multicolumn{5}{|l|}{$[\mathrm{PCM}=\mathrm{THF}]$} \\
\hline with counterion $\mathrm{Et}_{4} \mathrm{~N}^{+}$: & & & & \\
\hline $6-31+\mathrm{G}^{*}$ & -2.133 & 0.155 & 0.128 & 0.213 \\
\hline $6-311++\mathrm{G}^{* *} / 6-31+\mathrm{G}^{*}$ & -2.261 & 0.147 & 0.113 & 0.190 \\
\hline $\begin{array}{l}6-311++\mathrm{G}^{* *} / 6-31+\mathrm{G}^{*} \\
{\left[\mathrm{PCM}=\mathrm{CH}_{3} \mathrm{CN}\right]}\end{array}$ & -2.551 & 0.149 & 0.120 & 0.210 \\
\hline
\end{tabular}

DFT calculations indicate, that the spin and the charge in $\mathbf{1}^{-}-$ $4^{-}$, are delocalized within the $\pi$-electron system of the molecule. This includes the two mesitolyl substituents and the PO unit in $\mathbf{1}^{\mathbf{}}$, and one mesitolyl unit and the PO group in $\mathbf{2}^{-}$, as shown in Figure 4. The largest contributions to this $\pi$-type spin system are from the p-orbitals of the carbonyl group (ca. $70 \%$ for $\mathbf{2}^{-}$), the phosphorus atom $(15 \%)$ and the mesitoyl carbons (12\%). The singly-occupied molecular orbital of $\mathbf{2}^{-}$- (Figure 4) reflects this distribution. Although the values of the ${ }^{31} \mathrm{P}$ hfcs are relatively high, they reflect a small amount of the spin population at the $\mathrm{P}$ atom (since even a low spin population at phosphorus leads to large ${ }^{31} \mathrm{P}$ hfc values ${ }^{[8]}$ ). This is nicely illustrated by comparing $\mathbf{2}^{--}$with the corresponding phosphorus-centred diphenyl-phosphanoyl radical $\mathrm{Ph}_{2}(\mathrm{P} \bullet)=\mathrm{O}, \mathbf{P 2}$ (obtained by the photo-induced homolytic cleavage of the $\mathrm{P}-\mathrm{CO}$ bond in 2). $\mathbf{P 2}$ is well described, since its reactivity is the basis for the success of $\mathbf{2}$, as photoinitiator of radical polymerization. ${ }^{[1 \mathrm{a}, 1 \mathrm{~b}, 9]}$ In $\mathbf{P 2}$, the ${ }^{31} \mathrm{P}$ hfc amounts to $36.0 \mathrm{mT}^{[3 \mathrm{~g}, 3 \mathrm{i}, 10]}$, more than one order of magnitude larger than in $\mathbf{2}^{-}$. The reason for this immense difference is two-fold: $i$ ) the overall phosphorus spin population in $\mathbf{P 2}$ is exceedingly higher, and ii) the $s$-orbital character in $\mathbf{P 2}$ is more pronounced.

Thus, experiment and calculation both suggest that $1^{\mathbf{0}^{-}-\mathbf{4}^{-}}$are $\pi$-type delocalized radical anions.
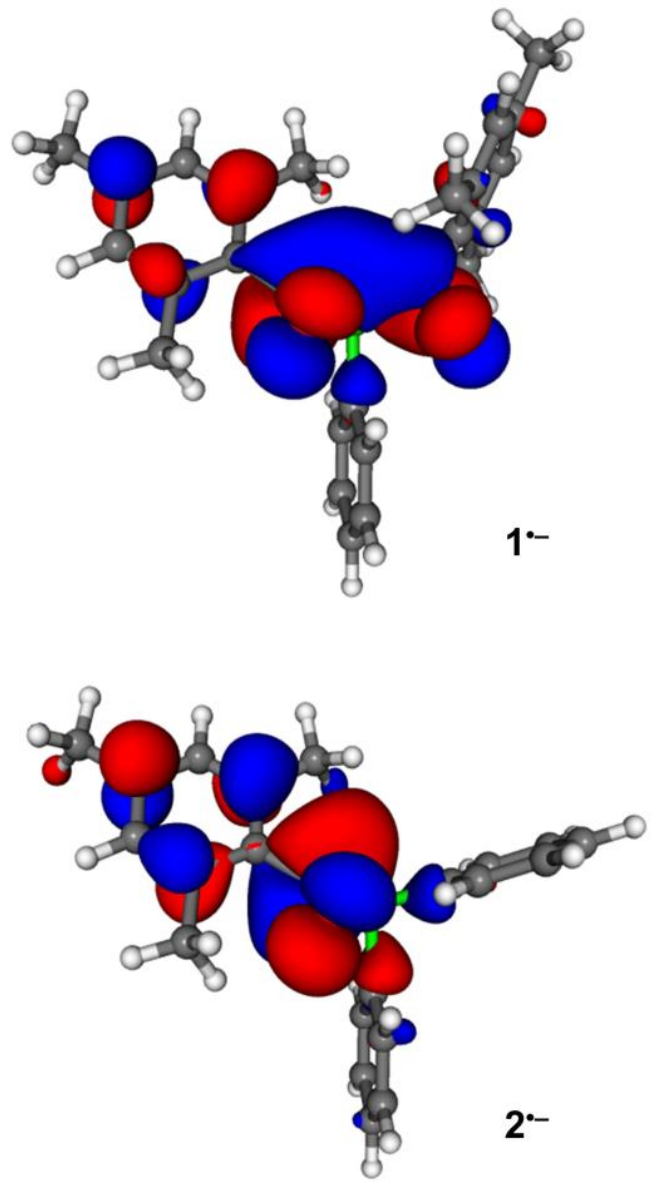

Figure 4. The lowest-energy conformers of $\mathbf{1}^{-}$and $\mathbf{2}^{--}$and their singly occupied molecular orbitals.

The reason for the diminished symmetry in $4^{--}$is very likely connected with the alkoxy chain, which, together with a single carbonyl group, is involved in a strong complexation of the counterion. Accordingly, an asymmetric spin distribution among the two mesitoyl units is induced. Here, binding and unbinding of the counterion, are slow at the hyperfine EPR time scale diminishing the overall symmetry.

\section{Conclusions}

We have shown that phosphane oxides display, in addition to their photochemical reactivity, a well-defined redox chemistry and form remarkably persistent radical anions. The electron distribution in these radical anions reflects the $\pi^{*}$-orbital. This property relates to the photochemistry of BAPOs where upon $n-\pi^{*}$ excitation, one $\mathrm{P}-\mathrm{C}$ bond breaks and the acyl group is cleaved off selectively in a Norrish type I reaction. ${ }^{[10 a]}$ A related follow-up reaction, the cleavage $\left[\mathrm{R}^{1} \mathrm{R}^{2} \mathrm{P}(=\mathrm{O}) \text {-COMes }\right]^{\bullet-} \rightarrow \mathrm{R}^{1} \mathrm{R}^{2} \mathrm{P}(=\mathrm{O})^{-}+\mathrm{MesCO}^{\bullet}$ contributes to the thermal instability of MAPO and BAPO radical anions. However, MAPOs and BAPOs may possess valuable properties, since $\pi-\pi^{*}$ transition-based electron transfer reactions could be coupled to the $n-\pi *$ type chemistry, as such transitions can be excited selectively, since they are well separated (Figure 4). 


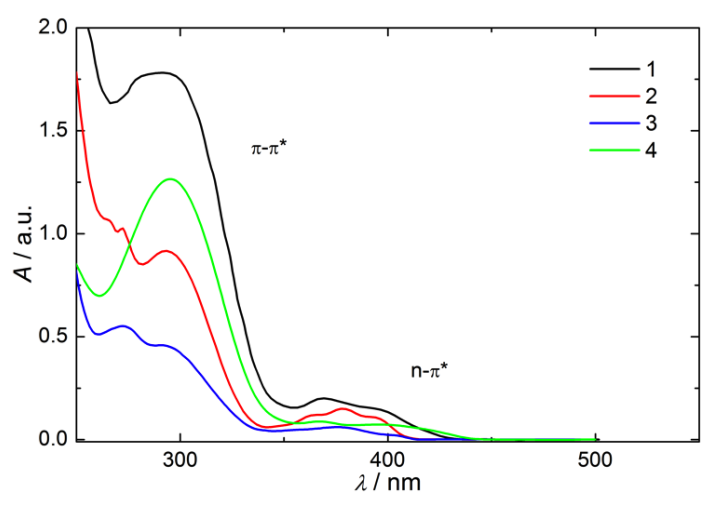

Figure 5. UV-VIS spectra of 1-4 displaying the regions for $\pi-\pi^{*}$ and $n-\pi^{*}$ transitions.

These distinct photochemical characteristics together with the electron distribution in the one-electron reduced stages of acylphosphane oxides, which is markedly different from the parent molecules, opens new opportunities for their chemical reactivity. This is the subject of on-going investigations.

\section{Experimental Section}

Materials. (Photoinitiators (PIs) 2,4,6-bis(trimethylbenzoyl)phenylphosphane oxide 1 (Irgacure ${ }^{\circledR} 819$ ) 2,4,6-trimethylbenzoyl)diphenylphosphane oxide 2 (Lucirin ${ }^{\circledR}$ TPO) and Ethyl-2,4,6trimethylbenzoylphenylphosphinate $\mathbf{3}$ (Lucirin ${ }^{\circledR}$ TPO-L) were purchased from BASF SE and were used as received.

The BAPO derivative 2,4,6- bis(trimethylbenzoyl)-(2-(2methoxyethoxy)ethyl)phosphane oxide $\mathbf{4}$ was prepared in $92 \%$ yield as yellow oil as reported in ref. ${ }^{[\mathrm{h}]}$ Acetonitrile (ROTIPURAN ${ }^{\circledR}, \geq 99,5 \%$, p.a.; Roth) and Tetrabutylammonium perchlorate $\left(\mathrm{N}(\mathrm{Bu})_{4} \mathrm{ClO}_{4}\right.$, puriss. electrochemical grade, Fluka, dried under reduced pressure at $340 \mathrm{~K}$ for $24 \mathrm{~h}$ prior to use) were used in the electrochemical experiments. Tetrahydrofuran (THF, Sigma-Aldrich) was heated to reflux over a $\mathrm{Na} / \mathrm{K}$ alloy and stored over a $\mathrm{Na} / \mathrm{K}$ alloy under high vacuum. Its deep blue color in combination with benzophenone was used as an indicator for rigorously water-free conditions.

Cyclic voltammograms (CV) were obtained with a PG580 potentiostat (Uniscan, UK) using the standard three electrode electrochemical cell with platinum disk working (WE) and counter (CE) electrodes and a silver wire pseudoreference electrode (RE). Approximately $1 \mathrm{mM}$ sample solutions were prepared in $\mathrm{CH}_{3} \mathrm{CN}$ with $0.1 \mathrm{M} \mathrm{N}(\mathrm{Bu})_{4} \mathrm{ClO}_{4}$ supporting electrolyte and purged with argon for 10 min before each experiment. CVs were recorded at the $100 \mathrm{mV} \mathrm{s}^{-1}$ scan rate. All potentials are given vs. $\mathrm{Fc} / \mathrm{Fc}^{+}$used as internal reference and are uncorrected from ohmic drop. EPR/ENDOR Spectroscopy Radical anions of 1-4 were prepared by controlled potential electrolysis in the $0.2 \mathrm{M}$

$\mathrm{N}(\mathrm{Bu})_{4} \mathrm{ClO}_{4} / \mathrm{CH}_{3} \mathrm{CN}$ solutions and/or by the chemical reduction in THF. The electrolysis was performed at ambient temperature, in situ in the cavity of the EPR spectrometer using EPR electrochemical flat cell (Pt mesh WE, $\mathrm{Pt}$ wire $\mathrm{CE}$ and $\mathrm{Ag}$ wire $\mathrm{RE})$ and applying potential $100 \mathrm{mV}$ more negative than the halfwave potential $\left(E_{1 / 2}\right)$ of the corresponding reduction process. Samples for the chemical reduction were prepared in a special three compartment EPR sample tube connected to the vacuum line. $\mathrm{K}$-metal mirror was sublimated to the wall of the tube and about $0.4 \mathrm{~mL}$ of THF was freshly condensed to dissolve the investigated

compound. The sample was successively degassed by three freezepump-thaw cycles and sealed under high vacuum. Reductions were performed by contact of the THF solution of the parent molecule with the K-metal mirror in the evacuated sample tube.

Two Bruker X-band spectrometers, EMX (100 kHz field modulation) and ESP 300 (equipped with an ENDOR unit, 12.5 $\mathrm{kHz}$ field modulation), both with an EUROTHERM temperature control unit, were used to record the cw-EPR and ENDOR spectra. Typical experimental conditions for the EPR spectra were $2 \mathrm{~mW}$ microwave power and $0.03 \mathrm{mT}$ field modulation. ENDOR spectra were recorded with $20 \mathrm{~mW}$ microwave power, $0.1 \mathrm{mT}$ field modulation, $10 \mathrm{MHz}$ pump frequency, $100 \mathrm{kHz}$ modulation depth and field locked at the maximum of the high field line of the phosphorus doublet. Spectra were analyzed with WinEPR and SimFonia software provided by the spectrometers manufacturer as well as with WinSim ${ }^{[11]}$, a public domain program.

Calculations

Software: Molecular dynamic simulations were performed with the program CHARMM ${ }^{[12]}$, version c36b1; clustering was done with the trajectory analysis tool Wordom $0.22^{[13]}$, version 0.22 ; and density functional theory (DFT) calculations were carried out with the program Gaussian09 ${ }^{[14]}$, RevA02.

Conformational sampling: A systematic conformational analysis was performed for radical anion $2^{--}$on the level UB3LYP/6-31+G* by a constrained scanning around the $\mathrm{P}-\mathrm{C}(=\mathrm{O})$ bond and one of the $\mathrm{P}-\mathrm{C}(\mathrm{Ph})$ bonds. Subsequent unconstrained geometry minimization and subsequent removal of conformational duplicates yielded a single conformer. In addition, we optimized the geometry of $\mathbf{2}^{-}$in the presence of counterions $\mathrm{K}^{+}$and $\mathrm{Et}_{4} \mathrm{~N}^{+}$which yielded three conformers.

For the more flexible systems $\mathbf{1}, \mathbf{3}$ and $\mathbf{4}$ we initially performed for their neutral state a $1-\mu$ s molecular dynamics simulation at $350 \mathrm{~K}$ using the Merck force-field MMFF (parameters were obtained from SwissParam ${ }^{[15]}$ ). Conformations were extracted every $100 \mathrm{ps}$ and minimized for 2000 steps of adopted basis Newton-Raphson prior to clustering ${ }^{[16]}$ using the root-mean-square deviation of nonhydrogen atoms as clustering criterion; the leader algorithm was applied with a cutoff criterion of $0.5 \AA$. Cluster headers were minimized as radical anions on the DFT level UB3LYP/6-31+G* and conformational duplicates were removed. This yielded six, ten and 44 confomers for radical anions $\mathbf{1}^{-}, \mathbf{3}^{-}$and $\mathbf{4}^{--}$, respectively. Calculation of electronic properties: Based on the UB3LYP/6$31+\mathrm{G}^{*}$-minimized structures, the potential energy and spin densities were determined by single-point calculations on the level UB3LYP/6-311++G**. In addition, we tested the effect of the solvent (THF) using the continuum solvation model PCM. ${ }^{[17]}$ Finally, the isotropic hyperfine coupling constants were calculated through a Boltzmann-weighted average over all confomers; the weight of a given conformer $i$ was

$$
p(i)=\frac{e^{\frac{-E(i)}{k_{\mathrm{B}} T}}}{Z}
$$

with $k_{\mathrm{B}}$ the Boltzmann constant, $T$ the temperature, and $E(i)$ the single-point energy of conformer $i ; Z$ is the sum of all weights. For chemically identical nuclei the mean value is reported in Table S2 (assuming fast exchange).

Supporting Information Analytical details on 4,EPR/ENDOR spectra of $\mathbf{3}^{-}$and $\mathbf{4}^{-}$, the complete set of calculated EPR data of $\mathbf{1}^{-} \mathbf{4}^{-}$, calculated orbital spin populations of $\mathbf{2}^{-}$, and a figure displaying populated conformations in $\mathbf{3}^{-}$.

\section{Acknowledgments}


Financial support from Graz University of Technology and the ProBono Stiftung (MZ) is gratefully acknowledged. PNS is supported by a fellowship from the Rhône-Alpes Region. PNS and MS are grateful for a CIBLE grant (Rhône-Alpes Region) and a grant for access to French supercomputing resources from the Grand Equipement National de Calcul Intensif (DARI x2013076381. We are also grateful to the Pôle Scientifique de Modélisation Numérique (ENS de Lyon) for computer time

[1] aK. Dietliker, T. Jung, J. Benkhoff, H. Kura, A. Matsumoto, H. Oka, D. Hristova, G. Gescheidt, G. Rist, Macromol. Symp. 2004, 217, 7797; bS. Jockusch, N. J. Turro, J. Am. Chem. Soc. 1998, 120, 1177311777; cI. V. Khudyakov, N. J. Turro, Photochem. UV Curing 2006, 241-251; dM. Spichty, N. J. Turro, G. Rist, J.-L. Birbaum, K. Dietliker, J.-P. Wolf, G. Gescheidt, J. Photochem. Photobiol. A 2001 142, 209-213; eN. J. Turro, I. V. Khudyakov, Res. Chem. Intermed. 1999, 25, 505-529; fM. Weber, N. J. Turro, D. Beckert, Phys. Chem. Chem. Phys. 2002, 4, 168-172; gY. Yagci, S. Jockusch, N. J. Turro, Macromolecules 2010, 43, 6245-6260; hA. Huber, A. Kuschel, T. Ott, G. Santiso-Quinones, D. Stein, J. Braeuer, R. Kissner, F. Krumeich, H. Schoenberg, J. Levalois-Gruetzmacher, H. Gruetzmacher, Angew. Chem., Int. Ed. 2012, 51, 4648-4652.

[2] N. S. Kenning, B. A. Ficek, C. C. Hoppe, A. B. Scranton, Polym. Int. 2008, 57, 1134-1140.

[3] aA. Borer, R. Kirchmayr, G. Rist, Helv. Chim. Acta 1978, 61, 305 324; bK. Dietliker, S. Broillet, B. Hellrung, P. Rzadek, G. Rist, J. Wirz, D. Neshchadin, G. Gescheidt, Helv. Chim. Acta 2006, 89, 2211-2225; cU. Kolczak, G. Rist, K. Dietliker, J. Wirz, J. Am. Chem. Soc. 1996, 118, 6477-6489; dM. Griesser, D. Neshchadin, K. Dietliker, N. Moszner, R. Liska, G. Gescheidt, Angew. Chem., Int. Ed. 2009, 48, 9359-9361; eG. S. Ananchenko, D. I. Potapenko, P. A. Purtov, E. G. Bagryanskaya, R. Z. Sagdeev, Appl. Magn. Reson. 2004, 26, 65-82; fH. Bock, K. Ruppert, C. Nather, Z. Havlas, H. F. Herrmann, C. Arad, I. Gobel, A. John, J. Meuret, S. Nick, A Rauschenbach, W. Seitz, T. Vaupel, B. Solouki, Angewandte Chemie-International Edition in English 1992, 31, 550-581; gI Gatlik, P. Rzadek, G. Gescheidt, G. Rist, B. Hellrung, J. Wirz, K. Dietliker, G. Hug, M. Kunz, J.-P. Wolf, J. Am. Chem. Soc. 1999, 121, 8332-8336; hD. Hristova, I. Gatlik, G. Rist, K. Dietliker, J.-P. Wolf, J.-L. Birbaum, A. Savitsky, K. Moebius, G. Gescheidt, Macromolecules 2005, 38, 7714-7720; iA. N. Savitsky, M. Galander, K. Mobius, Chem. Phys. Lett. 2001, 340, 458-466; jT. N. Makarov, A. N. Savitsky, K. Moebius, D. Beckert, H. Paul, J. Phys. Chem. A 2005, 109, 2254-2263; kG. W. Sluggett, P. F. McGarry, I. V. Koptyug, N. J. Turro, J. Am. Chem. Soc. 1996, 118, 7367-7372.

[4] aV. Cerri, P. Furderer, F. Gerson, P. Tordo, Nouveau Journal De Chimie-New Journal of Chemistry 1980, 4, 109-112; bV. Cerri, M. Boyer, P. Tordo, Tetrahedron Lett. 1979, 1437-1440.

[5] P. J. Wagner, R. J. Truman, A. E. Puchalski, R. Wake, J. Am. Chem. Soc. 1986, 108, 7727-7738.

[6] H. Bock, U. Lechnerknoblauch, P. Hanel, Chem. Ber. Recl. 1986 119, 3749-3765.

[7] aV. Barone, M. Biczysko, J. Bloino, F. Egidi, C. Puzzarini, J. Chem. Phys. 2013, 138, 234303/234301-234303/234314; bM. Renz, M. Kaupp, J. Phys. Chem. A 2012, 116, 10629-10637; cA. Polimeno, V. Barone, J. H. Freed, Computational Strategies for Spectroscopy 2012, 549-582; dL. Hermosilla, C. Sieiro, P. Calle, M. Zerbetto, A. Polimeno, J. Phys. Chem. B 2008, 112, 11202-11208; eL. Hermosilla, P. Calle, J. M. G. de la Vega, C. Sieiro, J. Phys. Chem. A 2005, 109, 7626-7635.
[8] J. R. Morton, K. F. Preston, Journal of Magnetic Resonance 1978, 30, 577-582.

[9] aC. S. Colley, D. C. Grills, N. A. Besley, S. Jockusch, P. Matousek, A. W. Parker, M. Towrie, N. J. Turro, P. M. W. Gill, M. W. George, J. Am. Chem. Soc. 2002, 124, 14952-14958; bI. Gatlik, P. Rzadek, G Gescheidt, G. Rist, B. Hellrung, J. Wirz, K. Dietliker, G. Hug, M. Kunz, J.-P. Wolf, J. Am. Chem. Soc. 1999, 121, 8332-8336; cM. Weber, N. J. Turro, D. Beckert, Phys. Chem. Chem. Phys. 2002, 4, 168-172.

[10] aP. Laurino, H. F. Hernandez, J. Braeuer, K. Krueger, H. Gruetzmacher, K. Tauer, P. H. Seeberger, Macromol. Rapid Commun. 2012, 33, 1770-1774; bL. Cataldo, C. Dutan, S. K. Misra, S. Loss, H. Grutzmacher, M. Geoffroy, Chemistry-a European Journal 2005, 11, 3463-3468; cW. B. Gara, B. P. Roberts, Journal of the Chemical Society-Perkin Transactions 2 1978, 150-154; dN. J. Turro, I. V. Khudyakov, Chem. Phys. Lett. 1992, 193, 546-552.

[11] D. R. Duling, Journal of Magnetic Resonance, Series B 1994, 104, 105-110.

[12] B. R. Brooks, C. L. Brooks, III, A. D. Mackerell, Jr., L. Nilsson, R. J. Petrella, B. Roux, Y. Won, G. Archontis, C. Bartels, S. Boresch, A Caflisch, L. Caves, Q. Cui, A. R. Dinner, M. Feig, S. Fischer, J. Gao, M. Hodoscek, W. Im, K. Kuczera, T. Lazaridis, J. Ma, V. Ovchinnikov, E. Paci, R. W. Pastor, C. B. Post, J. Z. Pu, M. Schaefer, B. Tidor, R. M. Venable, H. L. Woodcock, X. Wu, W. Yang, D. M. York, M. Karplus, J. Comput. Chem. 2009, 30, 1545-1614.

[13] M. Seeber, M. Cecchini, F. Rao, G. Settanni, A. Caflisch, Bioinformatics 2007, 23, 2625-2627.

[14] M. J. Frisch, G. W. Trucks, H. B. Schlegel, G. E. Scuseria, M. A. Robb, J. R. Cheeseman, G. Scalmani, V. Barone, B. Mennucci, G. A Petersson, H. Nakatsuji, M. Caricato, X. Li, H. P. Hratchian, A. F. Izmaylov, J. Bloino, G. Zheng, J. L. Sonnenberg, M. Hada, M. Ehara, K. Toyota, R. Fukuda, J. Hasegawa, M. Ishida, T. Nakajima, Y. Honda, O. Kitao, H. Nakai, T. Vreven, J. A. Montgomery, J. E. Peralta, F. Ogliaro, M. Bearpark, J. J. Heyd, E. Brothers, K. N. Kudin, V. N. Staroverov, R. Kobayashi, J. Normand, K. Raghavachari, A. Rendell, J. C. Burant, S. S. Iyengar, J. Tomasi, M. Cossi, N. Rega, J. M. Millam, M. Klene, J. E. Knox, J. B. Cross, V. Bakken, C. Adamo, J. Jaramillo, R. Gomperts, R. E. Stratmann, O. Yazyev, A. J. Austin, R. Cammi, C. Pomelli, J. W. Ochterski, R. L. Martin, K. Morokuma, V. G. Zakrzewski, G. A. Voth, P. Salvador, J. J. Dannenberg, S. Dapprich, A. D. Daniels, Farkas, J. B. Foresman, J. V. Ortiz, J. Cioslowski, D. J. Fox, Wallingford CT, 2009.

[15] V. Zoete, M. A. Cuendet, A. Grosdidier, O. Michielin, J. Comput. Chem. 2011, 32, 2359-2368.

[16] F. Rao, M. Karplus, Proceedings of the National Academy of Sciences of the United States of America 2010, 107, 9152-9157.

[17] M. Cossi, V. Barone, R. Cammi, J. Tomasi, Chem. Phys. Lett. 1996, 255, 327-335.

Received: ((will be filled in by the editorial staff)) Published online: ((will be filled in by the editorial staff)) 
Entry for the Table of Contents ((Please choose one layout.))

\section{Layout 1:}

((Key Topic))

(Bis)Acylphosphaneoxides, well established photoinitiators for radical polymerization, display a remarkable redox chemistry. They act as efficient electron acceptors. The corresponding radical anions are rather persistent and open novel opportunities for the use of this class of molecules.

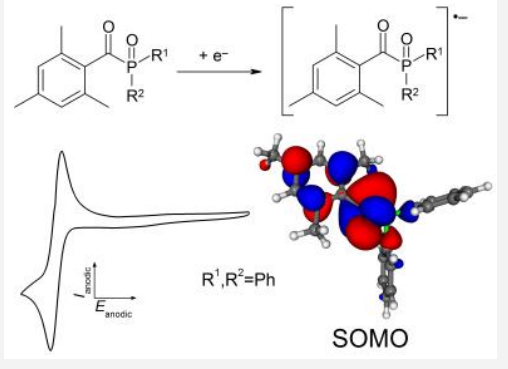

Michal Zalibera, Pierre-Nicolas

Stébé, Kurt Dietliker, Hansjörg

Grützmacher, Martin Spichty, and Georg Gescheidt*) ........ Page No. Page No.

((Title))

Keywords: Photoinitiator / Radical anion / Cyclovoltammetry / EPR 


\section{Supporting Information}

\section{Supporting Information}

The Redox Chemistry of (Bis)Acylphosphaneoxides

Michal Zalibera, ${ }^{\mathrm{a}}$ Pierre-Nicolas Stébé, ${ }^{\mathrm{c}}$ Kurt Dietliker, ${ }^{\mathrm{b}}$ Hansjörg Grützmacher, ${ }^{\mathrm{b}}$ Martin Spichty, ${ }^{\mathrm{c}}$ and Georg Gescheidt*,a

${ }^{a}$ Institute of Physical and Theoretical Chemistry, Graz University of Technology, Stremayrgasse 9, A-8010 Graz

${ }^{b}$ Department of Chemistry and Applied Biosciences, HCI H 131, CH-8093 Zürich

${ }^{c}$ Laboratory of Molecular and Cellular Biology, Differentiation and the Cell Cycle, Ecole Normale Supérieure de Lyon, 46, allée d'Italie,

69364 Lyon, cedex 07, France

\section{Experimental}

\subsection{Characterization of 4}

${ }^{1} \mathbf{H}$ NMR $\left(300 \mathrm{MHz}, \mathrm{C}_{6} \mathrm{D}_{6}, 25^{\circ} \mathrm{C}, \mathrm{TMS}\right): \delta=6.68(\mathrm{~s}, 4 \mathrm{H}, \mathrm{Mes}-\mathrm{CH}), 3.79\left(\operatorname{trd}, 2 \mathrm{H}, \mathrm{P}-\mathrm{CH}_{2}-\mathrm{CH}_{2}-\mathrm{O}\right.$ ), 3.34 $\left(\mathrm{m}, 2 \mathrm{H}, \mathrm{O}-\mathrm{CH}_{2}-\right), 3.18\left(\mathrm{~m}, 2 \mathrm{H}, \mathrm{O}-\mathrm{CH}_{2}-\right), 3.11$ (s, 3H, O-CH3 $), 2.58$ (dtr, $\left.2 \mathrm{H}, \mathrm{P}-\mathrm{CH}_{2}-\right), 2.54$ (s, $12 \mathrm{H}, \mathrm{o}-$ Mes- $\left.\mathrm{CH}_{3}\right), 2.08$ (s, $\left.6 \mathrm{H}, \mathrm{p}-\mathrm{Mes}-\mathrm{CH}_{3}\right) \mathrm{ppm}$;

${ }^{13}$ C NMR $\left(63 \mathrm{MHz}, \mathrm{C}_{6} \mathrm{D}_{6}\right): \delta=215.96\left(\mathrm{~d}, J_{\mathrm{PC}}=56.2 \mathrm{~Hz}, C=\mathrm{O}\right), 140.68\left(\mathrm{~s}, \mathrm{Mes}-C^{4}\right), 136.60\left(\mathrm{~s}\right.$, Mes- $\left.C^{1}\right)$, 136.41 (s, Mes- $\left.C^{3,5}\right), 129.25$ (s, Mes- $\left.C^{2,6}\right), 71.53\left(\mathrm{~s}, \mathrm{O}-\mathrm{CH}_{2}\right), 70.12\left(\mathrm{~s}, \mathrm{CH}_{2}-\mathrm{O}\right), 63.62\left(\mathrm{~d},{ }^{2} J_{\mathrm{CP}}=4.65 \mathrm{~Hz}\right.$, P- $\left.\mathrm{CH}_{2}-\mathrm{CH}_{2}\right), 58.25\left(\mathrm{~s}, \mathrm{O}-\mathrm{CH}_{3}\right), 28.20\left(\mathrm{~d},{ }^{2} J_{\mathrm{CP}}=54.78 \mathrm{~Hz}, \mathrm{P}-\mathrm{CH}_{2}-\mathrm{CH}_{2}\right), 20.83$ (s, Mes p- $\left.\mathrm{CH}_{3}\right), 20.09$ (s, Mes o- $\left.\mathrm{CH}_{3}\right) \mathrm{ppm}$;

${ }^{31} \mathbf{P}$ NMR $\left(121.5 \mathrm{MHz}, \mathrm{C}_{6} \mathrm{D}_{6}, 25^{\circ} \mathrm{C}, \mathrm{H}_{3} \mathrm{PO}_{4}\right) \delta=25.1$ (m) ppm;

FT-IR (ATR): $v=2915(\mathrm{vw}), 1754(\mathrm{vw}), 1674(\mathrm{w}, \mathrm{v}[\mathrm{C}=\mathrm{O}]), 1650(\mathrm{vw}), 1607(\mathrm{w}), 1444(\mathrm{w}), 1422(\mathrm{w})$, $1381(\mathrm{w}), 1354$ (w), $1297(\mathrm{vw}), 1278(\mathrm{vw}), 1250(\mathrm{vw}), 1200(\mathrm{~m}), 1180(\mathrm{w}), 1136(\mathrm{w}), 1112(\mathrm{~m}), 1102$ (m), $1034(\mathrm{w}), 1010(\mathrm{w}), 959(\mathrm{w}), 887(\mathrm{w}), 859(\mathrm{~m}), 850(\mathrm{~m}), 774(\mathrm{w}), 743(\mathrm{w}), 704(\mathrm{w}), 676(\mathrm{w}), 643$ (vw), $618(\mathrm{w}) \mathrm{cm}^{-1}$;

HRMS (ESI) calc. for $\mathrm{C}_{25} \mathrm{H}_{33} \mathrm{NaO}_{5} \mathrm{P} 467.1958$, found 467.1956.

\section{Results}

\subsection{EPR/ENDOR of $3^{\circ-}, 4^{--}$}


a) $3^{--} / \mathrm{N}(\mathrm{Bu})_{4}^{+}, \mathrm{CH}_{3} \mathrm{CN}, 298 \mathrm{~K}$

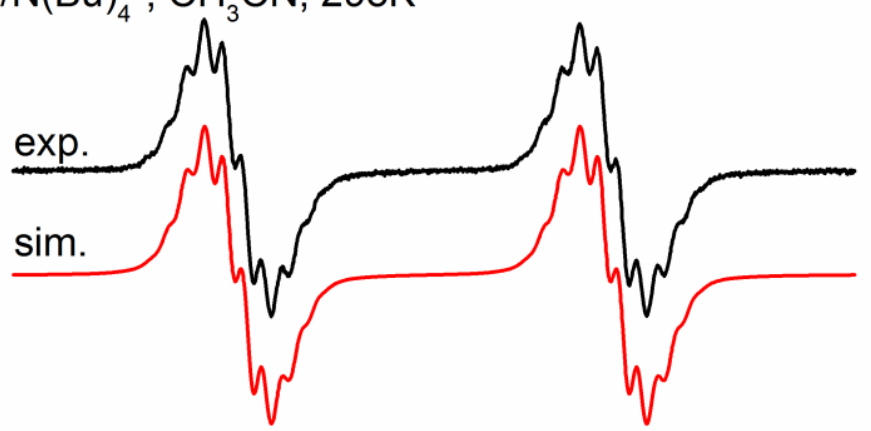

b) $3^{--} / \mathrm{K}^{+}, \mathrm{THF}, 200 \mathrm{~K}$

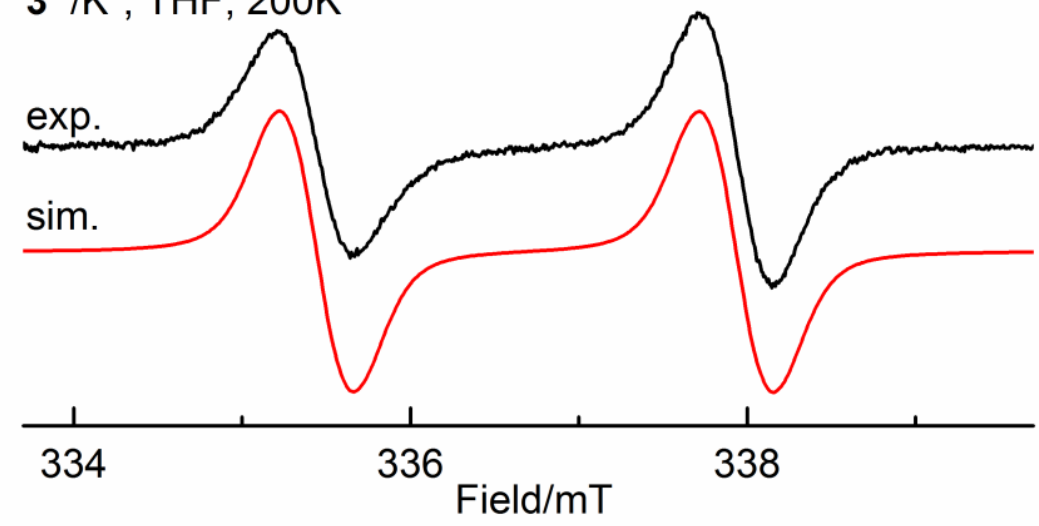

c) $3^{\cdot-} / \mathrm{K}^{+}, \mathrm{THF}, 200 \mathrm{~K}$
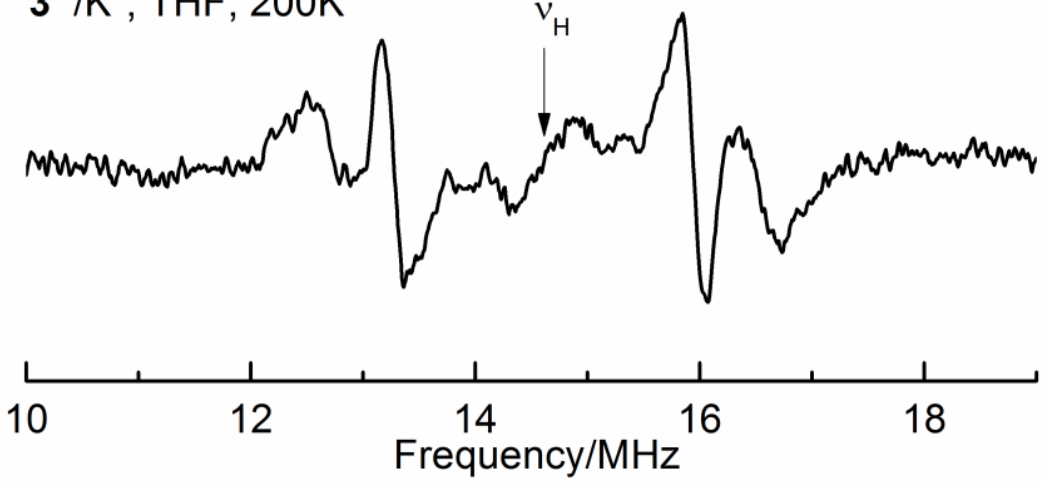

Figure S1. a) EPR spectrum obtained by electrochemical reduction (Pt cathode, $\mathrm{g}=2.0038$ ) of $\mathbf{3}$ (solvent $\mathrm{CH}_{3} \mathrm{CN}$, supporting electrolyte, $\mathrm{N}(\mathrm{Bu})_{4} \mathrm{ClO}_{4}$ ), with the simulation ; $\mathrm{T}=298 \mathrm{~K}$; b) EPR spectrum of 3 after chemical reduction with $\mathrm{K}$ in $\mathrm{THF}, \mathrm{T}=200 \mathrm{~K}$, with the simulation; c) corresponding ENDOR spectrum (THF, T = $200 \mathrm{~K}$ ). 
a) $4^{-\top} / \mathrm{N}(\mathrm{Bu})_{4}^{+}, \mathrm{CH}_{3} \mathrm{CN}, 298 \mathrm{~K}$

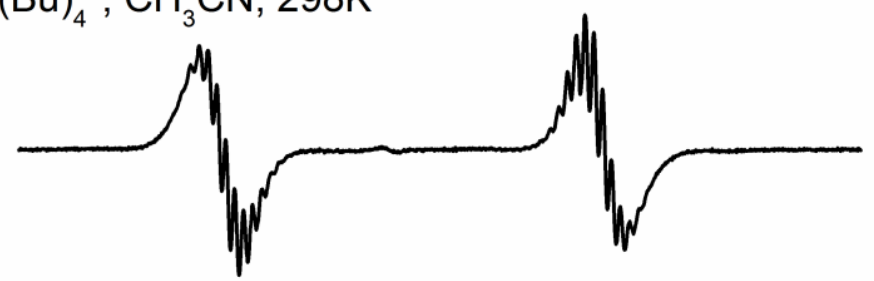

b) $4^{-}-\mathrm{K}^{+}, \mathrm{THF}, 200 \mathrm{~K}$

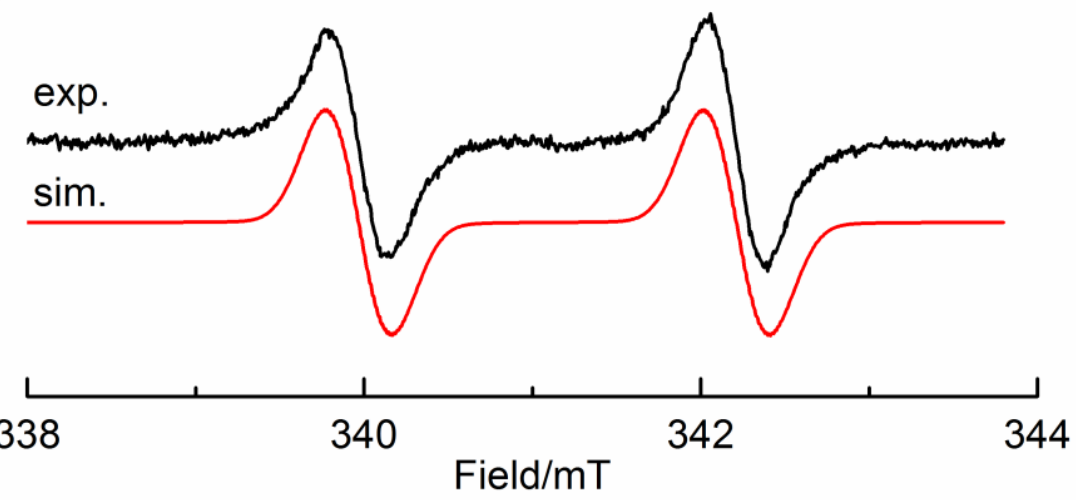

c) $4-/ \mathrm{K}^{+}, \mathrm{THF}, 200 \mathrm{~K}$

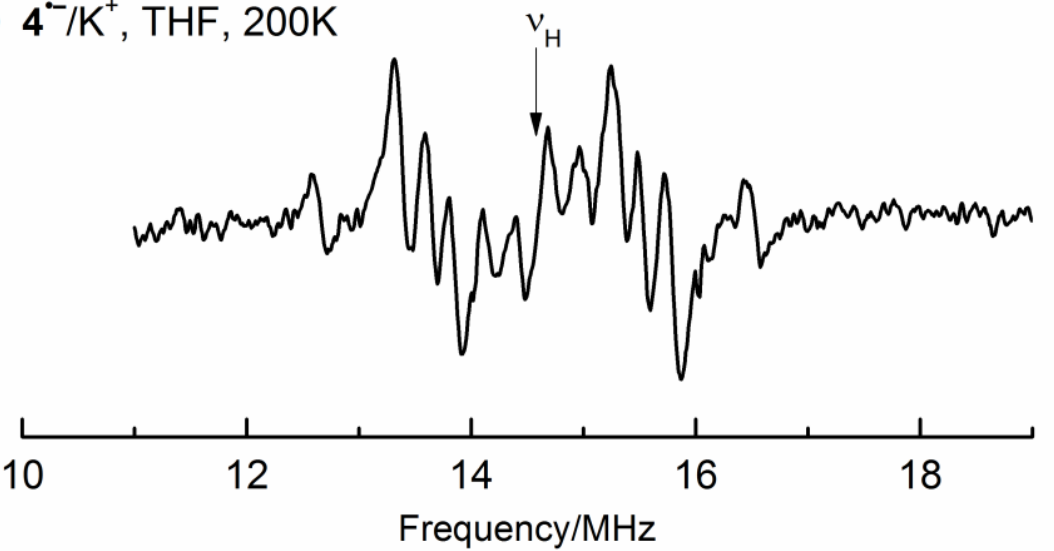

Figure S2. a) EPR spectrum obtained by electrochemical reduction (Pt cathode, $g=2.0044$ ) of 4 (solvent $\mathrm{CH}_{3} \mathrm{CN}$, supporting electrolyte, $\left.\mathrm{N}(\mathrm{Bu})_{4} \mathrm{ClO}_{4}\right) ; \mathrm{T}=298 \mathrm{~K} ; \mathrm{b}$ ) EPR spectrum of 4 after chemical reduction with $\mathrm{K}$ in THF, $\mathrm{T}=200 \mathrm{~K}$, with the simulation; c) corresponding ENDOR spectrum (THF, $\mathrm{T}=200 \mathrm{~K}$ ).

Table S1. EPR data of $\mathbf{1}^{-}-\mathbf{3}^{-}-(\mathrm{hfcs}$ are given in $\mathrm{mT})$ in $\mathrm{CH}_{3} \mathrm{CN} / \mathrm{N}(\mathrm{Bu})_{4}{ }^{+} 298 \mathrm{~K}$

\begin{tabular}{|c|c|c|c|c|c|c|c|}
\hline & ${ }^{31} \mathrm{P}$ & ${ }^{1} \mathrm{H}(o)$ & ${ }^{1} \mathrm{H}(p)$ & ${ }^{1} \mathrm{H}(m)$ & ${ }^{1} \mathrm{H}\left(o^{\prime}\right) \quad{ }^{1} \mathrm{H}\left(p^{\prime}\right)$ & ${ }^{1} \mathrm{H}\left(m^{\prime}\right)$ & $\mathrm{g}$ factor \\
\hline 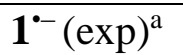 & 2.35 & $0.053(12)$ & $0.060(6)$ & & & & 2.0042 \\
\hline $2^{--}(\exp )^{a}$ & 2.43 & $0.119(6)$ & $0.165(3)$ & $0.104(2)$ & & & 2.0039 \\
\hline $3^{-}(\exp )^{a}$ & 2.23 & $0.094(6)$ & $0.134(3)$ & $0.026(2)$ & & & 2.0038 \\
\hline
\end{tabular}

${ }^{\text {a }}$ Spectra were recorded in $\mathrm{CH}_{3} \mathrm{CN}$ at $298 \mathrm{~K}$ 


\subsection{Calculations}

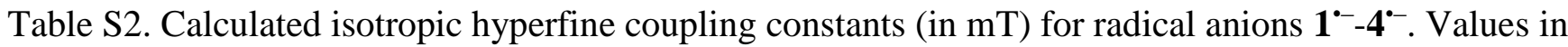
parentheses indicate the number of chemically equivalent nuclei.

Radical anion $\mathbf{1}^{\bullet-}$

\begin{tabular}{|c|c|c|c|c|c|c|c|}
\hline \multirow[b]{2}{*}{ Method } & \multirow[b]{2}{*}{$\begin{array}{l}\mathrm{P} \\
(1)\end{array}$} & \multicolumn{3}{|c|}{$\mathrm{H}$ - mesitoyl } & \multicolumn{3}{|c|}{ H - phenyl } \\
\hline & & $\begin{array}{c}\text { ortho-Me } \\
\text { (12) }\end{array}$ & $\begin{array}{c}\text { meta } \\
(4)\end{array}$ & $\begin{array}{c}\text { para-Me } \\
\text { (6) }\end{array}$ & $\begin{array}{l}\text { ortho } \\
(2)\end{array}$ & $\begin{array}{c}\text { meta } \\
(2)\end{array}$ & $\begin{array}{c}\text { para } \\
(1)\end{array}$ \\
\hline $6-31+G^{*}$ & -1.728 & 0.102 & 0.060 & 0.128 & 0.029 & 0.010 & -0.012 \\
\hline $6-311++\mathrm{G}^{* *}$ & -1.986 & 0.082 & 0.049 & 0.101 & 0.050 & 0.007 & -0.002 \\
\hline $6-311++\mathrm{G}^{* *}[\mathrm{PCM}=\mathrm{THF}]$ & -2.067 & 0.079 & 0.052 & 0.095 & 0.049 & 0.008 & -0.001 \\
\hline \multicolumn{8}{|l|}{ Radical anion $\mathbf{2}^{\bullet-}$} \\
\hline & D & \multicolumn{3}{|c|}{$\mathrm{H}-$ mesitoyl } & \multicolumn{3}{|c|}{ H - phenyl } \\
\hline Method & (1) & $\begin{array}{c}\text { ortho-Me } \\
\text { (6) }\end{array}$ & $\begin{array}{c}\text { meta } \\
(2)\end{array}$ & $\begin{array}{c}\text { para-Me } \\
\text { (3) }\end{array}$ & $\begin{array}{l}\text { ortho } \\
(4)\end{array}$ & $\begin{array}{c}\text { meta } \\
(4)\end{array}$ & $\begin{array}{l}\text { para } \\
(2)\end{array}$ \\
\hline $6-31+G^{*}$ & -2.029 & 0.209 & 0.131 & 0.282 & 0.010 & 0.007 & -0.020 \\
\hline $6-311++\mathrm{G}^{* *}$ & -2.395 & 0.200 & 0.121 & 0.275 & 0.012 & 0.006 & -0.017 \\
\hline $6-311++\mathrm{G}^{* *}[\mathrm{PCM}=\mathrm{THF}]$ & -2.502 & 0.205 & 0.130 & 0.281 & 0.015 & 0.008 & -0.012 \\
\hline \multicolumn{8}{|l|}{ with counterion: } \\
\hline $6-31+\mathrm{G}^{*}$ & -2.385 & 0.108 & 0.112 & 0.119 & -0.009 & 0.010 & -0.023 \\
\hline $6-311++\mathrm{G}^{* *}$ & -2.773 & 0.104 & 0.106 & 0.117 & -0.008 & 0.009 & -0.020 \\
\hline $6-311++\mathrm{G}^{* *}[\mathrm{PCM}=\mathrm{THF}]$ & -2.724 & 0.107 & 0.106 & 0.123 & -0.008 & 0.009 & -0.020 \\
\hline
\end{tabular}

Radical anion $\mathbf{3}^{\bullet}$

\begin{tabular}{|c|c|c|c|c|c|c|c|c|c|}
\hline \multirow[b]{2}{*}{ Method } & \multirow{2}{*}{$\begin{array}{l}\mathrm{P} \\
(1)\end{array}$} & \multicolumn{3}{|c|}{$\mathrm{H}$ - mesitoyl } & \multicolumn{3}{|c|}{ H - phenyl } & \multirow{2}{*}{\multicolumn{2}{|c|}{$\begin{array}{c}\mathrm{H}-\text { alkc } \\
\text { methylen } \\
(2)\end{array}$}} \\
\hline & & $\begin{array}{c}\text { ortho-Me } \\
\text { (6) }\end{array}$ & $\begin{array}{c}\text { meta } \\
(2)\end{array}$ & $\begin{array}{c}\text { para-Me } \\
\text { (3) }\end{array}$ & $\begin{array}{l}\text { ortho } \\
\text { (2) }\end{array}$ & $\begin{array}{c}\text { meta } \\
(2)\end{array}$ & $\begin{array}{c}\text { para } \\
(1)\end{array}$ & & \\
\hline $6-31+\mathrm{G}^{*}$ & -1.657 & 0.173 & 0.110 & 0.230 & -0.046 & 0.025 & -0.093 & & 0.010 \\
\hline $6-311++\mathrm{G}^{* *}$ & -2.018 & 0.163 & 0.101 & 0.220 & -0.039 & 0.023 & -0.085 & & 0.009 \\
\hline $6-311++\mathrm{G}^{* *}[\mathrm{PCM}=\mathrm{THF}]$ & -2.086 & 0.169 & 0.111 & 0.226 & -0.031 & 0.023 & -0.067 & & 0.009 \\
\hline \multicolumn{10}{|l|}{ Radical anion $\mathbf{4}^{\bullet-}$} \\
\hline & $P$ & \multicolumn{3}{|c|}{$\mathrm{H}-$ mesitoyl } & \multicolumn{5}{|c|}{$\mathrm{H}$ - alkoxy } \\
\hline Method & (1) & $\begin{array}{c}\text { ortho-Me } \\
\text { (12) }\end{array}$ & $\begin{array}{c}\text { meta } \\
(4)\end{array}$ & $\begin{array}{c}\text { para-Me } \\
(6)\end{array}$ & $\begin{array}{c}\alpha \\
(2)\end{array}$ & $\begin{array}{c}\beta \\
(2)\end{array}$ & $\begin{array}{c}\gamma \\
(2)\end{array}$ & $\begin{array}{c}\delta \\
(2)\end{array}$ & $\begin{array}{c}\text { methyl } \\
\text { (3) }\end{array}$ \\
\hline $6-31+\mathrm{G}^{*}$ & -1.535 & 0.089 & 0.053 & 0.108 & -0.028 & 0.017 & 0.000 & 0.000 & 0.000 \\
\hline $6-311++\mathrm{G}^{* *}$ & -1.804 & 0.083 & 0.048 & 0.102 & -0.023 & 0.016 & 0.000 & 0.000 & 0.000 \\
\hline $6-311++\mathrm{G}^{* *}[\mathrm{PCM}=\mathrm{THF}]$ & -1.915 & 0.084 & 0.052 & 0.103 & -0.022 & 0.017 & 0.000 & 0.000 & 0.000 \\
\hline
\end{tabular}


Table S3. Gross orbital spin population of radical anion $\mathbf{2}^{- \text {- }}$ (unbound and $\mathrm{K}^{+}$-bound). The sum of the spin population through $s^{-}, p^{-}$, and $d$-orbitals is given for the atom types of different chemical groups.

\begin{tabular}{|c|c|c|c|c|c|c|c|}
\hline \multirow{3}{*}{$\begin{array}{l}\text { group } \\
\text { name }\end{array}$} & \multirow{3}{*}{$\begin{array}{l}\text { atom } \\
\text { type }\end{array}$} & \multicolumn{3}{|c|}{ Radical anion $2^{\circ-}$} & \multicolumn{3}{|c|}{ Radical anion $2^{--} / \mathrm{K}^{+}$} \\
\hline & & & orbital & & & orbital & \\
\hline & & $s$-type & $p$-type & $d$-type & $s$-type & $p$-type & $d$-type \\
\hline \multirow[t]{2}{*}{ mesitoyl } & $\mathrm{C}$ & 0.008 & 0.118 & 0.013 & -0.022 & 0.043 & 0.012 \\
\hline & $\mathrm{H}$ & 0.044 & 0.000 & & 0.033 & 0.000 & \\
\hline \multirow[t]{2}{*}{ phenyl } & $\mathrm{C}$ & -0.160 & 0.064 & 0.000 & 0.038 & -0.061 & 0.001 \\
\hline & $\mathrm{H}$ & -0.008 & 0.000 & & -0.016 & 0.000 & \\
\hline \multirow[t]{2}{*}{ carbonyl } & $\mathrm{C}$ & 0.022 & 0.429 & 0.006 & 0.046 & 0.466 & 0.005 \\
\hline & $\mathrm{O}$ & 0.007 & 0.265 & 0.000 & 0.004 & 0.256 & 0.000 \\
\hline \multirow[t]{2}{*}{ phosphoryl } & $\mathrm{P}$ & -0.001 & 0.174 & 0.020 & -0.045 & 0.260 & 0.025 \\
\hline & $\mathrm{O}$ & 0.001 & -0.005 & 0.000 & -0.074 & 0.016 & 0.000 \\
\hline counterion & $\mathrm{K}$ & & & & 0.005 & 0.005 & 0.001 \\
\hline
\end{tabular}




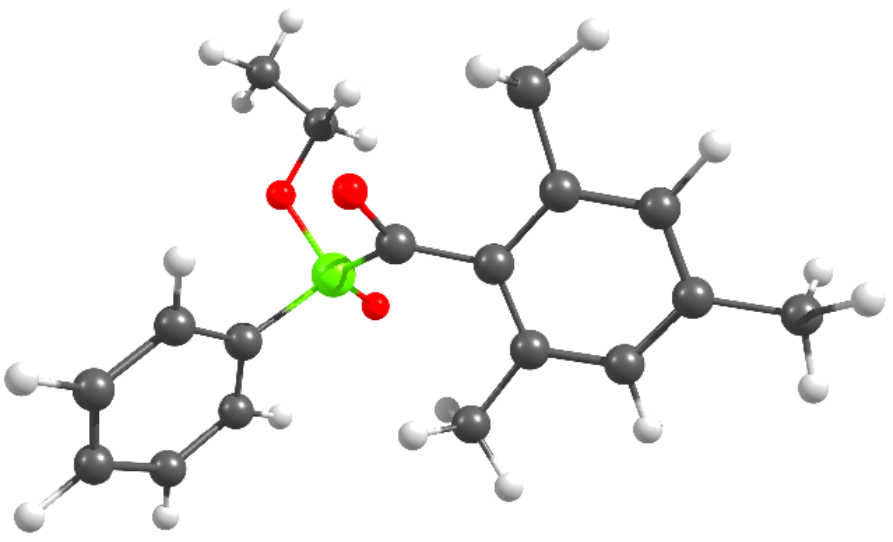

hfc ${ }^{31} \mathrm{P}=2.405 \mathrm{mT}$

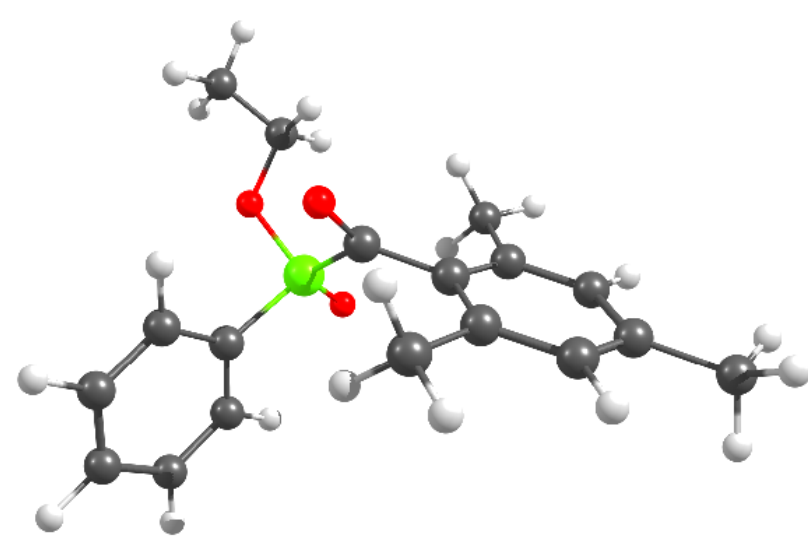

hfc ${ }^{31} \mathrm{P}=1.884 \mathrm{mT}$

Figure S3. The two most populated conformers of radical anion $3^{\circ}$. The energy difference is 0.04 $\mathrm{kcal} / \mathrm{mol}$. A 90-degree rotation around the $\mathrm{C}(=\mathrm{O})-\mathrm{C}(\mathrm{Mes})$ bond changes the ${ }^{31} \mathrm{P}$ hfc by more than 0.5 $\mathrm{mT}$. 